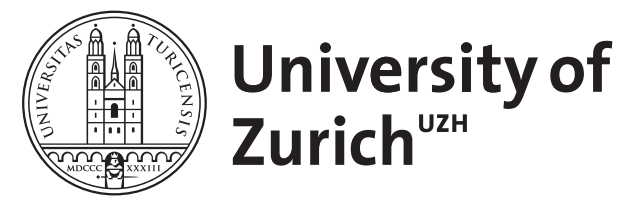

\title{
Patolli Petroglyphs in Northeast Honduras
}

Fecher, Franziska

\begin{abstract}
Patolli petroglyphs were recently identified at two archaeological sites in northeast Honduras. Patolli is a Mesoamerican game of chance described in ethnohistoric sources and documented in archaeological contexts in many parts of Mesoamerica. Thus, it has been characterized as an important element of Mesoamerican culture. The existence of patolli boards at Plan Grande, on the island of Guanaja, and at Sawacito in northeast Honduras shows that the practice of the game extended farther to the east than earlier presumed and indicates long-distance interaction. Given the considerable number of five patolli petroglyphs at Plan Grande, I characterize the site as an important center.
\end{abstract}

DOI: https://doi.org/10.1017/laq.2019.52

Posted at the Zurich Open Repository and Archive, University of Zurich ZORA URL: https://doi.org/10.5167/uzh-179178

Journal Article

Published Version

Originally published at:

Fecher, Franziska (2019). Patolli Petroglyphs in Northeast Honduras. Latin American Antiquity, 30(3):624-629.

DOI: https://doi.org/10.1017/laq.2019.52 


\title{
Patolli Petroglyphs in Northeast Honduras
}

\author{
Franziska Fecher
}

\begin{abstract}
Patolli petroglyphs were recently identified at two archaeological sites in northeast Honduras. Patolli is a Mesoamerican game of chance described in ethnohistoric sources and documented in archaeological contexts in many parts of Mesoamerica. Thus, it has been characterized as an important element of Mesoamerican culture. The existence of patolli boards at Plan Grande, on the island of Guanaja, and at Sawacito in northeast Honduras shows that the practice of the game extended farther to the east than earlier presumed and indicates long-distance interaction. Given the considerable number of five patolli petroglyphs at Plan Grande, I characterize the site as an important center.
\end{abstract}

Keywords: northeast Honduras, Isthmo-Colombian Area, prehispanic games, petroglyphs

Recientemente se han identificado petroglifos de patolli en dos sitios arqueológicos en el noreste de Honduras. Patolli es un juego de azar prehispánico descrito en fuentes etnohistóricas y documentado en contextos arqueológicos en muchas zonas de Mesoamérica. Ha sido reconocido como un elemento importante de la cultura mesoamericana y la existencia de varios tableros de patolli en los sitios de Plan Grande, Guanaja y Sawacito, Olancho, demuestra que la práctica de este juego se extendió más allá de las fronteras tradicionales de Mesoamérica e indica un intercambio a larga distancia. La presencia de cinco petroglifos de patolli en Plan Grande sugiere que éste era un centro de encuentro importante.

Palabras clave: noreste de Honduras, área istmo-colombiana, juegos prehispánicos, petroglifos

$\mathrm{T}$ his report identifies and describes patolli petroglyphs at the archaeological sites Plan Grande on the island of Guanaja and at Sawacito in the department of Olancho in northeast Honduras (Figure 1). Illustrations in earlier reports on Plan Grande (ELAP 2006; Feachem 1940) attracted my attention, because they very closely resembled patolli petroglyphs but were not identified as such. Another patolli petroglyph was recognized in photos from Sawacito that were shown to the author. During a visit to Plan Grande in 2018, I aimed to relocate the previously published petroglyphs. Additionally, we documented three new patolli petroglyphs at the site. In the following report, I describe the petroglyphs at Plan Grande and Sawacito, including their respective archaeological contexts.

\section{The Patolli Game}

The patolli game has been the subject of various publications (e.g., Caso 1925; Mountjoy and Smith 1985; Smith 1977; Swezey and Bittman 1983; Voorhies 2013; Walden and Voorhies 2017). Most of the information about it originates from ethnohistorical sources about Aztec society (Durán 1971 [15741579]:302f; Sahagún 1938:298, 320). They explain that the popular game was often played during feasts and that it was tied to religious practice and cosmovision. Beans ( patol) were used as dice, and tokens were set on a scoreboard that consisted of a cross or $\mathrm{x}$-shaped pattern subdivided into quadrangular fields, sometimes accompanied by an additional frame of fields.

Franziska Fecher $\mathbf{~ D e p a r t m e n t ~ o f ~ A r c h a e o l o g y , ~ U n i v e r s i t y ~ o f ~ Z u r i c h , ~ K a r l ~ S c h m i d - S t r a s s e ~ 4 , ~ C H - 8 0 0 6 ~ Z u r i c h , ~ S w i t z e r l a n d ~}$ (franziska.fecher@uzh.ch) 




Figure 1. Left, location of Plan Grande and Sawacito in Honduras; right, sketch of Plan Grande based on Strong (1935: Figure 35), with the approximate location of the petroglyphs.

Game boards that closely resemble those described in ethnohistorical sources and depicted in codices have been found in archaeological contexts and are believed to be the precursors of the colonial-period game (Figure 2). Although Barbara Voorhies (2013) shows that the roots of the game might be much older, the first known game boards date to the Early Classic period (AD 300-600) and appear in central Mexico and the Maya Lowlands. In later periods, they are also present in West Mexico and the Gulf Coast (111f). Most of the archaeological patolli boards are found engraved into flat stone slabs or scratched into plaster floors, whereas among the Aztec it was common to paint the board on mats (Durán 1971).

Swezey and Bittman (1983:405, 413) state that, based on its temporal depth and geographical distribution, the patolli game was an integral part of Mesoamerican culture. To the best of my knowledge, there is no documentation of the game in an archaeological context outside the traditional frontiers of Mesoamerica.

\section{Patolli Petroglyphs at Plan Grande, Guanaja}

\section{The Plan Grande Site, Guanaja}

Plan Grande lies on Guanaja, the easternmost of the Honduran Bay Islands. The site is located on the northeastern section of the island and consists of at least 10 flat earthen mounds that stretch out on a flat terrain (Figure 1). The mounds are associated with monolithic stone slabs and formations of upright standing stones. The northern part of the site is enclosed by a low boulder wall, and the southern area is delimited by a narrow
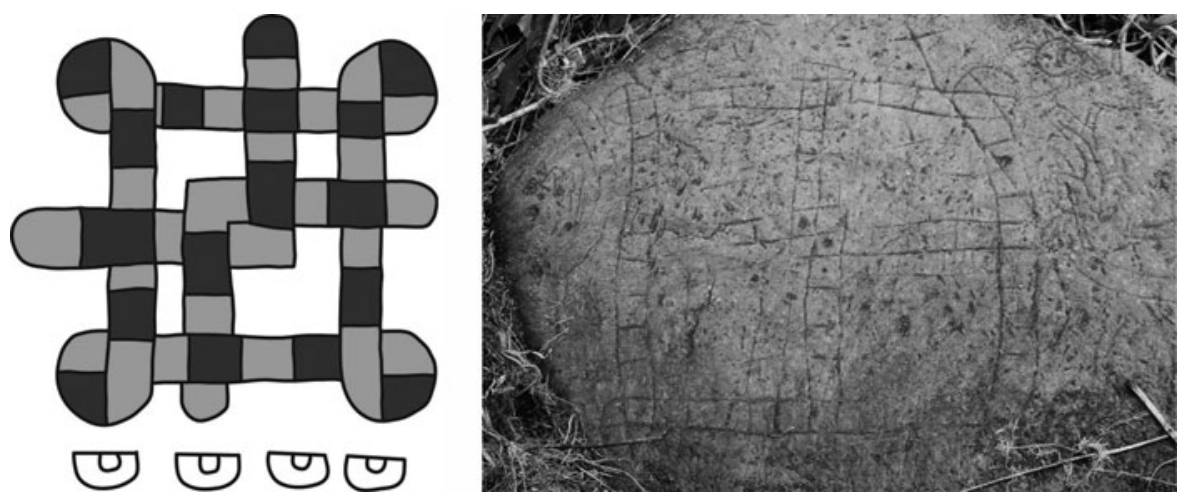

Figure 2. Patolli boards: left, as illustrated on p. 62 of the Codex Borgia (drawing by F. Fecher); right, petroglyph documented near Sawacito (photograph courtesy of C. Woda). 
stream. Based on pottery fragments excavated at the site by William D. Strong (1935), Plan Grande can roughly be dated to the Selin (AD 300-1000) and Cocal (AD 1000-1525) periods.

Although Plan Grande has never been excavated intensively, it was the site of several brief investigations. It was first mentioned in the midnineteenth century (Young 1842:48). In the 1930s, it was visited by F. A. Mitchell-Hedges and the Boekelman Shell-Heap expedition. Both teams conducted surveys, excavated test pits and collected objects. The most detailed account, however, is given by Strong (1935); because the previous expeditions did not yield scientific publications, their results were partly summarized by him. He created a site map and concluded that Plan Grande must have been of a ceremonial character based on the lack of abundant potsherds and refuse heaps and the nature of the stone alignments. The first to explicitly mention and illustrate a stone with a patolli design at Plan Grande, although it was not recognized as such at the time, was R. W. Feachem (1940).

After this rather concentrated interest, the island seems to have fallen into oblivion. Short visits were paid among others by Alan Craig (1977) and the Honduran Institute of Anthropology and History (IHAH; Cruz Castillo 1999). The last major project commissioned by the IHAH was to design an archaeological park in the surroundings of the site (ELAP 2006). During the project, nine monolithic stone slabs were mapped, including the one previously illustrated by Feachem, but the engravings seem not to have been noticed. Instead, the surveyors emphasized another stone with a similar design. Once again, the design was not identified as a patolli game board.

\section{New Investigations at Plan Grande}

During a visit to Plan Grande in 2018, we were able to find the two stones reported by Feachem and the ELAP. Three other slabs showed vague engravings, and we documented all five stones with photographs from which 3D models were created by Michael Lyons. The original models were generated using Agisoft Photoscan software. Rendering the images with a radiance scaling shader in MeshLab made visible that which was not visible to the naked eye: each stone is engraved with a patolli petroglyph (Figure 3 ).

All of the five patolli boards at Plan Grande are located on heavy, flat stone slabs and are engraved in low relief. The engravings are about $1 \mathrm{~m}$ wide and show a similar design: a cross subdivided into quadrangular fields framed by a square also subdivided into fields. The corners of the frame are twisted and formed by four fields, respectively. Each petroglyph shows little variation.

Petroglyph 1. Petroglyph 1 is the petroglyph documented by Feachem (1940). His illustration shows that at two points, the arms of the cross extend beyond the frame and form additional fields. Swezey and Bittman (1983:383) note that such fields might have served as entries or exits to the game. The petroglyph includes 72 fields. It is associated with small, round cavities aligned with respect to one another, which might have served as another kind of game.

Petroglyph 2. Petroglyph 2 is the petroglyph documented by the ELAP (2006). The slab that bears the petroglyph is broken, which is why only part of the petroglyph is visible; sediment covers a large part of the slab. The petroglyph consists of a framed cross. Its center is formed by four fields. Presumably, it consists of 72 fields. It is associated with spirals and round and oval cavities of different sizes.

Petroglyph 3. The lower half of petroglyph 3 is especially visible. Assuming that its design is symmetrical, it most likely consists of a cross with four fields at its center, as well as an additional field where each arm of the cross meets the frame. Hence, it is composed of 76 fields. It is associated with spirals and individual small cavities.

Petroglyph 4. Some parts of petroglyph 4 are not well preserved, but in its center we can recognize four fields. I assume that there are at least two additional fields where the arms of the cross meet the frame. Thus, the petroglyph is composed of either 74 or 76 fields. It is also associated with parallel lines of small cavities.

Petroglyph 5. Petroglyph 5 is in a poor state of conservation, which is why I can only speculate as to its design. Most likely, it has four fields at its center. If there are any extending fields, they are not clearly visible. The petroglyph is associated with small cavities that run in parallel lines over the patolli petroglyph. 


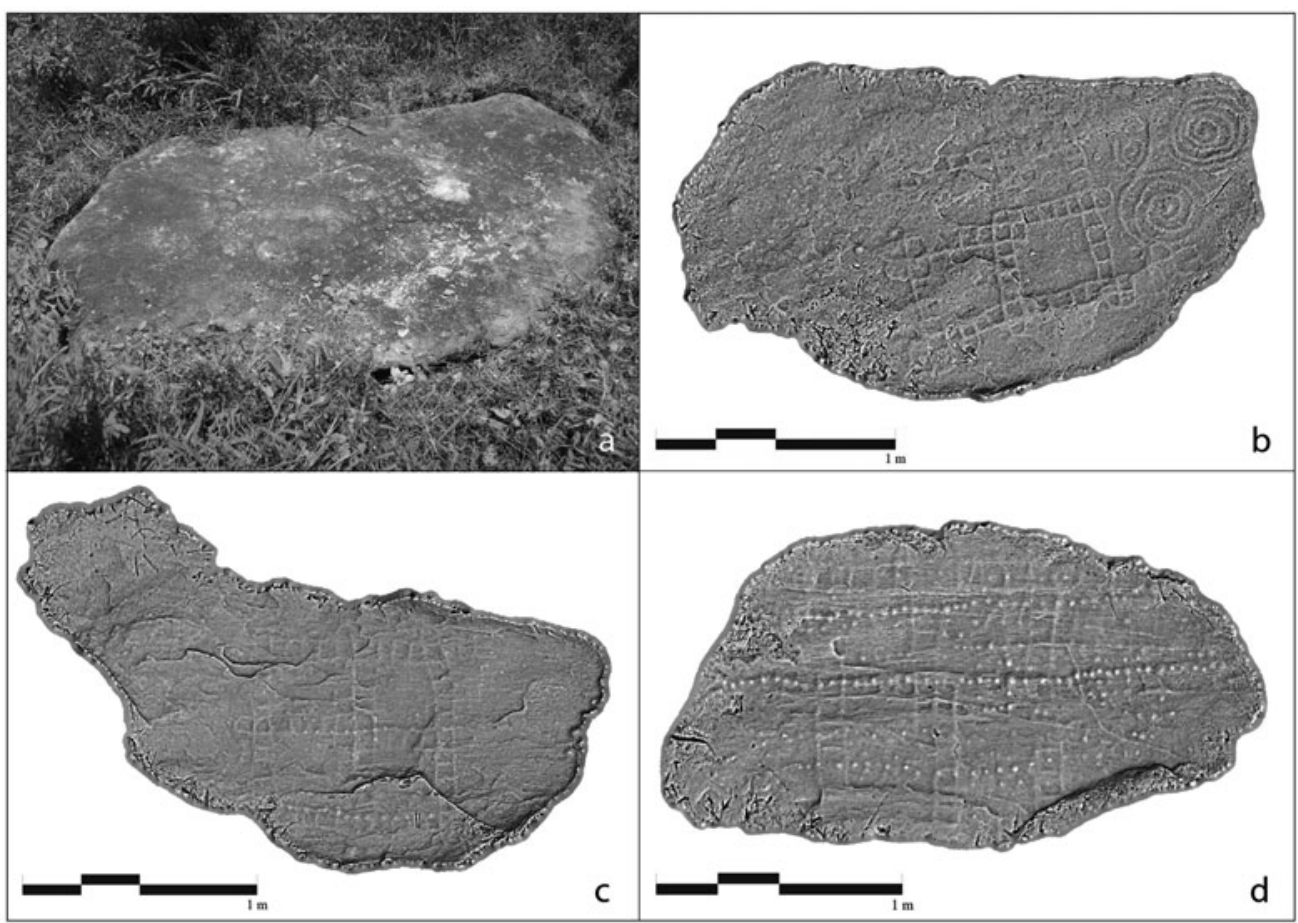

Figure 3. Patolli petroglyphs at Guanaja: (a) photograph of petroglyph 3, on which vague engravings can be seen; (b) 3D model of petroglyph 3, on which the patolli design becomes visible; (c) 3D model of petroglyph 4; (d) 3D model of petroglyph 5 (3D models courtesy of $M$. Lyons).

Given that not all of the stone slabs at Plan Grande were recorded photogrammetrically, it is likely that more stones with patolli design exist at the site and its vicinity. ${ }^{1}$

\section{Patolli Petroglyph at Sawacito}

Sawacito is located in the buffer zone of the Rio Plátano Biosphere Reserve on the Honduran mainland (see Figure 1). The area adjoins the so-called Mosquitia and is part of the largest coherent zone of tropical rainforest in Central America. As of yet, the region has been poorly studied archaeologically, not least because of its limited infrastructure and inaccessibility. The few investigators who have ventured into the region include Herbert Spinden (1925), William D. Strong (1934), Christopher Begley (1999), and archaeologists of the IHAH (e.g., Lara Pinto and Hasemann 1991). In the last few years, the region has attracted attention because of the identification of sizable prehispanic settlements through lidar flights (Fisher et al. 2016).

The flat stone slab with a patolli petroglyph (Figure 2) was discovered by Christine Woda during fieldwork carried out by the German Corporation for International Cooperation (GIZ) to promote sustainable management of the Rio Platano preserve. Sawacito consists of several earthen mounds clearly visible on the surface and has not yet been investigated. The petroglyph is carved in low relief and measures about $1 \mathrm{~m}$ in width. It consists of a cross with a frame, and the corners are each formed by four fields. In contrast to the Guanaja petroglyphs, the corners are rounded. The center of the cross is formed by four squares, so that the petroglyph consists of 72 fields in total. The petroglyph shows additional incisions and scratches, but judging from their lower depth, it is most likely that they do not belong to the original petroglyph. The patolli petroglyph is associated with zoomorphic petroglyphs. 


\section{Discussion and Conclusion}

These petrographs show that patolli boards not only existed in Mesoamerica, but also that the game was played beyond the traditional frontiers of this cultural region. Northeast Honduras is seen as part of the Isthmo-Colombian Area, although studies carried out there make it clear that it had its own distinctive cultural characteristics (Healy 1984; Reindel et al. 2018). The distribution of the patolli boards broadens the evidence that long-distance interaction was taking place between the inhabitants of the regions (e.g., Begley 1999). As to its regional and temporal definition, there are only vague hints available to better define this interaction. Stylistically, the petroglyphs mostly resemble Type I of Swezey and Bittman's typology (1983). This type is known from central Mexico and is depicted in codices, which indicates some kind of connection between that region and the inhabitants of Plan Grande and Sawacito during the Postclassic period. However, more data, especially regarding the sites where the patolli petroglyphs were found, are needed to corroborate such a hypothesis.

What the existence of patolli petroglyphs in Northeast Honduras does suggest is that the interaction was not only limited to economic interests but also included the exchange of ideas. Although the extent to which worldviews or religious practices associated with the game were transported remains unclear at this point, we need to keep in mind that, in Mesoamerica, the boards were often found in the context of ceremonial structures and the game was deeply tied to religious practice. This makes it very probable that playing patolli was more than a leisure activity for the inhabitants of Plan Grande and Sawacito. The existence of at least five patolli petroglyphs at Plan Grande indicates that the site was an important center: it likely was a meeting place where gatherings were held accompanied by gaming activities and feasts. Certainly, the game played an important role among the prehispanic inhabitants of Guanaja.

Acknowledgments. This article presents some of the findings of the Proyecto Arqueológico Guadalupe, which receives grant funding from the Swiss-Liechtenstein Foundation for Archaeological Research Abroad, the German Archaeological Institute, and the University of Zurich. I am especially grateful to Prof. Dr. Markus Reindel, Prof. Dr. Philippe Della Casa and the Honduran Institute of Anthropology and History. I would like to thank Michael Lyons for making the 3D models, the PAG-team for all its support, Hans Weller and Edgardo Ortega for their assistance, Dr. Christine Woda for permission to use her illustration, and the three anonymous reviewers for their helpful comments.

Data Availability Statement. 3D models are stored in the digital archives of the German Archaeological Institute.

\section{Note}

1 Mitchell-Hedges mentions another stone with "rectangular lines around a cross" (Strong 1935:129) in the proximity of Marble Hill, an archaeological site near Plan Grande.

\section{References Cited}

Begley, Christopher

1999 Elite Power Strategies and External Connections in Ancient Eastern Honduras. PhD dissertation, Department of Anthropology, University of Chicago.

Caso, Alfonso

1925 Un antiguo juego mexicano: El Patolli. El México Antiguo 2:203-211.

Craig, Alan K.

1977 Contribución a la prehistoria de las Islas de la Bahía. Yaxkin 2:19-27.

Cruz Castillo, Oscar N.

1999 Informe de inspección a los sitios arqueológicos de Plan Grande y Marble Hill, Guanaja, Islas de la Bahía, Honduras. Manuscript on file, Instituto Hondureño de Antropología e Historia, Tegucigalpa.

Durán, Diego

1971 [1574-1579] Book of the Gods and Rites and the Ancient Calendar. Translated and edited by Fernando Horcasitas and Doris Heyden. University of Oklahoma Press, Norman.

ELAP (Escuela Latinoamericana de Áreas Protegidas)

2006 Plan de manejo y gestión: Parque Arqueológico Plan Grande, Isla Guanaja, Islas de la Bahía, Honduras. ELAP, San José, Costa Rica.

Feachem, Richard W.

1940 The Bay Islands, Gulf of Honduras. Geographical Journal 96:181-189.

Fisher, Christopher T., Juan Carlos Fernández-Diaz, Anna S. Cohen, Oscar N. Cruz, Alicia M. Gonzáles, Stephen J. Leisz, Florencia Pezzutti, Ramesh Shrestha, and William Carter

2016 Identifying Ancient Settlement Patterns through LiDAR in the Mosquitia Region of Honduras. PloS ONE 11(8):e0159890. https://doi.org/10.1371/journal. pone.0159890.

Healy, Paul

1984 Northeast Honduras: A Precolumbian Frontier Zone. In Recent Developments in Isthmian Archaeology. Advances in the Prehistory of Lower Central America. Proceedings of the 44th International Congress of Americanists, edited by Frederick Lange and Norman Hammond, pp. 227-241. British Archaeological Reports, Oxford.

Lara Pinto, Gloria, and George Hasemann

1991 Leyendas y arqueología: Cuantas ciudades blancas 
hay en la Mosquitia? In La Reserva de la Biósfera del Río Plátano: Herencia de nuestro pasado, edited by Vicente Murphy, pp. 16-19. Ventanas Tropicales, Tegucigalpa.

Mountjoy, Joseph B., and John P. Smith

1985 An Archaeological Patolli from Tomatlan, Jalisco, Mexico. In Contributions to the Archaeology and Ethnohistory of Greater Mesoamerica. Publications in Archaeology, edited by William J. Folan and Carroll L. Riley, pp. 240-262. Southern Illinois University Press, Carbondale.

Reindel, Markus, Peter Fux, and Franziska Fecher

2018 Archäologisches Projekt Guadalupe: Bericht über die Feldkampagne 2017. In Schweizerisch-Liechtensteinische Stiftung für archäologische Forschungen im Ausland, Jahresbericht 2017, edited by Schweizerisch-Liechtensteinische Stiftung für archäologische Forschungen im Ausland, pp. 31-47. Schweizerisch-Liechtensteinische Stiftung für archäologische Forschungen im Ausland, Zurich.

Sahagún, Bernardino de

1938 Historia general de las cosas de Nueva España, Vol II. Pedro Robredo, Mexico City.

Smith, A. Ledyard

1977 Patolli, at the Ruins of Seibal, Petén, Guatemala. In Social Process in Maya Prehistory: Studies in Honour of Sir Eric Thompson, edited by Norman Hammond, pp. 349-364. Academic Press, London.

Spinden, Herbert J.

1925 The Chorotegan Culture Area. Proceedings of the Twenty-first International Congress of Americanists 2:529-545. Brill, Leiden.
Strong, William D.

1934 Hunting Ancient Ruins in Northeast Honduras. In Explorations and Fieldwork of the Smithsonian Institution in 1933, edited by W. P. True, pp. 44-47. Smithsonian Institution, Washington, DC.

1935 Archaeological Investigations in the Bay Islands, Spanish Honduras. Smithsonian Institution Publication 3290. Smithsonian Institution, Washington, DC.

Swezey, William R., and Bente Bittman

1983 El rectángulo de cintas y el patolli: Nueva evidencia de la antigüedad, distribución, variedad y formas de practicar este juego precolombino. Mesoamérica 4:373-416.

Voorhies, Barbara

2013 The Deep Prehistory of Indian Gaming: Possible Late Archaic Period Game Boards at the Tlacuachero Shellmound, Chiapas, Mexico. Latin American Antiquity 24:98-115.

Walden, John, and Barbara Voorhies

2017 Ancient Maya Patolli. In Prehistoric Games of North American Indians: Subarctic to Mesoamerica, edited by Barbara Voorhies, pp. 197-218. University of Utah Press, Salt Lake City.

Young, Thomas

1842 Narrative of a Residence on the Mosquito Shore, During the Years 1839, 1840, \& 1841: With an Account of Truxillo, and the Adjacent Islands of Bonacca and Roatan; and a Vocabulary of the Mosquitian Language. Smith, Elder \& Co, London.

Submitted January 2, 2019; Revised April 8, 2019; Accepted June 11, 2019 